\title{
EFFECT OF TREATMENT WITH ARABIC GUM ON RATS SUFFERING FROM CHRONIC RENAL FAILURE EXPERIMENTAL BIOLOGY
}

\author{
By \\ Abd El-Rahman Attia \\ Nutrition and Food Sci. Dept., Fac. of \\ Home Economic, Halwan Univ., Cairo, \\ Egypt. \\ Samah, M. Ismael \\ Home Economic Dept. Fac. of Edu., Ain \\ Shams Univ., Cairo, Egypt \\ Ashraf, A. Abdel-Megeid \\ Nutrition and Food Sci. Dept., Fac. of \\ Home Economic, Halwan Univ., Cairo, \\ Egypt. \\ Noorah. A. A. Alsheredah \\ Home Economic Dept. Fac. of Edu., Ain \\ Shams Univ., Cairo, Egypt
}

\section{Research Gournal Specific Fducation \\ Faculty of Specific Education \\ Mansoura University}

ISSUE NO. 26, YULY. 2012

$$
\begin{aligned}
& \text { مجلة بحوث التربية النوعية - جامعة المنصورة }
\end{aligned}
$$

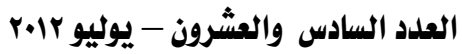




\section{EFfect of TREATMENT WITH ARABIC GUM ON RATS SUfFerING}

FROM CHRONIC RENAL FAILURE: EXPERIMENTAL BIOLOGY

Abd El-Rahman Attia"

Samah, M. Ismael ${ }^{* * *}$
Ashraf, A. Abdel-Megeid ${ }^{*}$

Noorah. A. A. Alsheredah ${ }^{* *}$

\section{Abstract}

The present work was conducted to study the effect of diets containing different levels from protein with or without oral administration of gum Arabic on rats suffering from chronic renal failure. Two main experimental groups were established. Group $1(\mathrm{n}=7$ rats $)$ used as a negative control group fed on basal diet (B.D). The other group $(\mathrm{n}=49$ rats) fed two weeks on diet containing $2 \%$ arginine $(\mathrm{W} / \mathrm{W})$ to induce renal failure, then this group was divided into seven subgroups (7rats each). The first subgroup fed on diet containing 2\% arginine (arginine diet), as a control positive group. Subgroups (2, 3 and 4) fed on arginine diets containing 5\%, 10\% and 20\% protein, respectively. Subgroups (5, 6 and 7) fed on arginine diets containing the above levels of protein and treated daily with $(10 \%$ gum Arabic w/v) in the drinking water. Feeding rats on arginine diet decreased the mean value of food intake, body weight gain $\%$, serum HDL-c and serum sodium, while organs weight/body weight \%, serum (cholesterol, triglycerides, LDL-c, VLDL-c, uric acid, urea nitrogen, creatinine, potassium, AST and ALT) increased significantly, as compared to the negative control group fed on basal diet. Treating rats which suffer from chronic renal failure with medium and low levels from protein improved these parameters, especially with low level. On the other hand, treating rats which were suffering from chronic renal failure daily with $(10 \%$ gum Arabic w/v) in the drinking water recorded more effects in improving these parameters, especially when used gum Arabic with low level from protein. The present study suggested that, using the gum Arabic with low protein diet must be implemented for chronic renal failure patients. In the same time nutritional and health educational programs should be organized and directed for public to protect themselves from this disease.

Key words: Arabic Gum; Albino Rats; Arginine; Chronic Renal Failure, Lipid Profile; Kidney Functions - Liver Enzymes.

\footnotetext{
* Nutrition and Food Science Dept., Faculty of Home Economics, Helwan University

** Home Economic Dept. Fac. of Edu., Ain Shams Univ., Cairo, Egypt.
} 
EFFECT OF TREATMENT WITH ARABIC GUM ON RATS SUFFERING

FROM CHRONIC RENAL FAILURE: EXPERIMENTAL BIOLOGY

\author{
Abd El-Rahman Attia* \\ Samah, M. Ismael ${ }^{* *}$ \\ Ashraf, A. Abdel-Megeid ${ }^{*}$ \\ Noorah. A. A. Alsheredah ${ }^{* *}$
}

\title{
INTRODUCTION :
}

Acacia gum (gum Arabic) is the dried gummy exudate of the stem and branches of acacia trees (Senegal family, leguminosae). It consists mainly of a calcium salt of polyarabic acid, but also contains magnesium and potassium ions. It is a high-molecular weight polysaccharide, which on hydrolysis yields hexoses, arabinose, galactose, rhamnose, and glucoronic acid. Acacia gum is generally recognized as safe by the United States Food and Drug Administration. It is widely used in the production of foods, such as puddings, frostings, candy, chewing gum, and beverages. It has demulcent properties and is often added to medicines (Phillips, 1998).

Ali et al., (2010) reported that, oral administration of gum Arabic could conceivably alleviate adverse effects of chronic renal failure (CRF). Gum Arabic (GA) is a complex polysaccharide used as suspending agent. It has been widely used by eastern folk medicine practitioners as a restorative agent and is thought to be an excellent curative for renal failure patients.

Abdulhakeem et al., (2002) reported that, Arabic gum (AG) protected the rats from gentamicin (GM)-induced nephrotoxicity, possibly, at least in part through inhibition of the production of oxygen free radicals that cause lipid peroxidation. Gum Arabic is a non-digestible food ingredient that has found many applications in the food and pharmaceutical industries. The gums claimed therapeutic usefulness in hepatic and renal failure awaits further verification in animal models and humans. No significant adverse or toxic actions have been associated with the use of gum Arabic.

High protein diet has been proposed to increase exogenous acid load and to result in a chronic low - grade metabolic acidosis. Nitrogen must be separated from the protein molecule and processed by the liver. The kidney must then filter the excess nitrogen out of the body. The more protein eats the harder liver and kidneys must work to accomplish this task (Locatelli,

\footnotetext{
* Nutrition and Food Science Dept., Faculty of Home Economics, Helwan University

** Home Economic Dept. Fac. of Edu., Ain Shams Univ., Cairo, Egypt.
} 
2004). Reducing protein intake in patients with chronic renal failure reduces the occurrence of renal death by about $40 \%$, as compared with larger or unrestricted protein intake Denis et al., (2000). The present work was conducted to study the effect of diets containing different levels from protein with or without oral administration of gum Arabic on rats suffering from chronic renal failure.

\section{MATERIALS AND METHODS:}

\section{Materials:}

- Acacia gum was obtained from Agriculture Research Center, Cairo, Egypt.

- Casein, vitamins, minerals, cellulose, choline chloride and arginine were purchased from El-Gomhorya Company, Cairo Egypt.

- Fifty six male albino rats of Sprague Dawley strain weighting an average body weight $(200 \pm 10 \mathrm{~g})$ were obtained from Laboratory of Animal Colony, Helwan, Egypt.

\section{Methods:}

\section{Preparation of samples:}

Acacia gum was soaked in boiling water $\left(100^{\circ} \mathrm{C}\right)$ for $15 \mathrm{~min}$. and prepared to be drinking water $\left(10 \%\right.$ Arabic Gum w/v) at $20-25^{\circ} \mathrm{C}$ and kept in glass bottle for biological evaluation.

\section{Biological assay:}

Fifty six male albino rats of Sprague Dawely strain weighting an average $200 \pm 10 \mathrm{~g}$ body weight were housed in well aerated cages under hygienic laboratory conditions in the animal house of Faculty of Home Economics, Helwan University, the rats were fed on basal diet for one week for acclimatization and water was provided ad libitum. After this week, the rats were divided in to two main groups as follow:

The first main group ( $\mathrm{n}=7$ rats) fed on basal diet (prepared according to Reeves et al., 1993), as a control negative group, while the second main group ( $\mathrm{n}=49$ rats) fed two weeks on diet containing $2 \%$ arginine $(\mathrm{W} / \mathrm{W})$ to induce renal failure according to the method described by (Yokozawa et al., 2003). Then, the second main group divided into seven subgroups (7rats each).

The first subgroup fed on diet containing $2 \%$ arginine, as a control positive group. Subgroup (2) fed on low protein diet (diet containing 5\% 
protein) $+2 \%$ arginine. Subgroup (3) fed on medium protein diet (diet containing $10 \%$ protein) $+2 \%$ arginine. Subgroup (4) fed on high protein diet (diet containing $20 \%$ protein) $+2 \%$ arginine. Subgroup (5) fed on low protein diet (diet containing $5 \%$ protein) $+2 \%$ arginine and treated daily with $(10 \%$ gum Arabic w/v) in the drinking water. Subgroup (6) fed on medium protein diet (diet containing $10 \%$ protein) $+2 \%$ arginine and treated daily with $(10 \%$ gum Arabic w/v) in the drinking water. Subgroup (7) fed on high protein diet (diet containing $20 \%$ protein) $+2 \%$ arginine and treated daily with $(10 \%$ gum Arabic w/v) in the drinking water. As illustrated in (Table 1).

Table 1: Composition of the diets (g/kg_1) fed to the investigated male albino rats.

\begin{tabular}{|c|c|c|c|c|c|c|c|c|}
\hline \multirow[t]{3}{*}{ Ingredients } & \multicolumn{2}{|c|}{ Controls } & \multicolumn{6}{|c|}{ Arginine diet } \\
\hline & \multirow[t]{2}{*}{$\begin{array}{c}* \text { Control } \\
\text { (-ve) }\end{array}$} & \multirow[t]{2}{*}{$\begin{array}{c}\text { Control } \\
(+\mathrm{ve})\end{array}$} & \multicolumn{3}{|c|}{ Without Arabic Gum } & \multicolumn{3}{|c|}{$\begin{array}{c}\text { With (10\% Arabic } \\
\text { Gum w/v) in drinking } \\
\text { water }\end{array}$} \\
\hline & & & $\begin{array}{c}5 \% \\
\text { protein } \\
\end{array}$ & $\begin{array}{c}10 \% \\
\text { protein } \\
\end{array}$ & $\begin{array}{c}20 \% \\
\text { protein } \\
\end{array}$ & $\begin{array}{c}5 \% \\
\text { protein } \\
\end{array}$ & $\begin{array}{c}10 \% \\
\text { protein }\end{array}$ & $\begin{array}{c}20 \% \\
\text { protein } \\
\end{array}$ \\
\hline Corn starch & 662.5 & 642.5 & 792.5 & 742.5 & 642.5 & 792.5 & 742.5 & 642.5 \\
\hline Casein & 200 & 200 & 50 & 100 & 200 & 50 & 100 & 200 \\
\hline Corn Oil & 40 & 40 & 40 & 40 & 40 & 40 & 40 & 40 \\
\hline Mineral mixture & 35 & 35 & 35 & 35 & 35 & 35 & 35 & 35 \\
\hline Vitamin mixture & 10 & 10 & 10 & 10 & 10 & 10 & 10 & 10 \\
\hline Cellulose & 50 & 50 & 50 & 50 & 50 & 50 & 50 & 50 \\
\hline Choline chloride & 2.5 & 2.5 & 2.5 & 2.5 & 2.5 & 2.5 & 2.5 & 2.5 \\
\hline Arginine & --- & 20 & 20 & 20 & 20 & 20 & 20 & 20 \\
\hline
\end{tabular}

During the experimental period (28 days), the diets consumed and body weights were recorded twice weekly. At the end of the experiment, the animals were fasted overnight, then the rats were anaesthetized and sacrificed, and blood samples were collected from the aorta. blood samples were centrifuged and the serum was separated to estimate some biochemical parameters, serum cholesterol by (Allain et al., 1974), triglycerides by (Fossati and principe 1982), HDL-c by (Lopes-Virella 1977), LDL-c \& VLDL-c estimated according to the method of (Assmann, et al. 1984), uric acid by (Fossati et al., (1980), urea nitrogen by (Patton and Crouch, 1977), creatinine by (Bohmer, 1971), Serum AST \& ALT by (Reitman and Frankel, 1957), sodium and potassium according to the methods described by (Henry et al., 1974). 
Kidneys, heart and liver were removed from each rat, careful dissection, washed with saline solution, dried with filter paper and weighed according to the method described by (Drury and Wallington, 1980). The kidney and liver in each group was examined histopathologicaly, according to (Sheehan and Hrapchak 1980). All data were subjected to statistical analysis according to the procedure reported by Snedecor \& Cochran, (1980) and the statistical analysis system program (SAS, 1996) using Student's t-test.

\section{RESULTS AND DISCUSSION:}

Effect of diets contains different levels from protein in the presence of Arabic Gum on food intake, body weight gain \% and some organs weight $/$ body weight $\%$ of rats suffering from chronic renal failure.

The mean values \pm standard deviation of food intake (g/day), body weight gain $\%$ and liver \& kidney weight/body weight $\%$ for normal group (ve control group), chronic renal failure group (+ve control group) and chronic renal failure groups fed on diets containing different levels from protein in the presence or absent of Arabic Gum are illustrated in table (1).

Table (1) Effect of diets containing different levels from protein in the presence of Arabic Gum on food intake and body weight gain \% of rats suffering from chronic renal failure.

\begin{tabular}{|c|c|c|c|c|}
\hline \multirow{2}{*}{$\begin{array}{l}\text { Parameters } \\
\text { Groups } \\
\end{array}$} & \multirow{2}{*}{$\begin{array}{c}\text { Food intake } \\
(\mathrm{g} / \text { day/rat })\end{array}$} & \multirow{2}{*}{ Body weight gain $\%$} & \multicolumn{2}{|c|}{ Organs weight / body weigh \% } \\
\hline & & & Liver & Kidney \\
\hline Control (-ve) & 16.531 & $26.270 \pm 3.198 \mathrm{a}$ & $2.861 \pm 0.105 \mathrm{~g}$ & $0.571 \pm 0.051 \mathrm{~d}$ \\
\hline Control (+ve) & 13.650 & 7.475 & $3.750 \pm 0$ & $31 \mathrm{a}$ \\
\hline $5 \%$ protein & 14. & $11.272 \pm 1.588 \mathrm{bc}$ & $3.322 \pm 0.120 \mathrm{~cd}$ & $0.682 \pm 0.060 \mathrm{c}$ \\
\hline $10 \%$ protein & 14.815 & $12.818 \pm 1.799 \mathrm{bc}$ & $3.452 \pm 0.084 b \mathrm{c}$ & $0.763 \pm 0.059 \mathrm{~b}$ \\
\hline $20 \%$ protein & 15.600 & $12.985 \pm 1.675 \mathrm{bc}$ & $3.622 \pm 0.085 \mathrm{ab}$ & $0.840 \pm 0.072 \mathrm{ab}$ \\
\hline $5 \%$ protein $+A G$ & & $=1.087 \mathrm{~d}$ & $2.900 \pm 0.0$ & $0.586 \pm 0$ \\
\hline $10 \%$ protein $+\mathrm{AG}$ & & & $3.052 \pm 0$. & $0.616 \pm 0.049 \mathrm{c} \mathrm{d}$ \\
\hline $20 \%$ protein $+\mathrm{AG}$ & 16.211 & $13.722 \pm 0.610 \mathrm{~b}$ & $3.109 \pm 0.135 \mathrm{~d} \mathrm{e}$ & $\pm 0.053 \mathrm{~cd}$ \\
\hline
\end{tabular}

- Values are expressed as mean \pm SD.

- AG: Arabic Gum Significant at $\mathrm{p}<0.05$ using one way ANOVA test.

-Values which have different letters in each column differ significantly, while those with have similar or partially are not significant.

The mean value of food intake decreased in chronic renal failure (CRF) group fed on diet containing $2 \%$ arginine, as compared to normal group fed on basal diet (B.D) negative group. Chronic renal failure groups which fed on diets containing different levels from protein $(5 \%, 10 \%$ and 
$20 \%)$ and treated or non-treated daily with (10\% Arabic Gum w/v) in the drinking water increased the mean value of food intake, as compared to the positive control group. The highest increase in the mean value of food intake recorded for the group fed on diet containing $20 \%$ protein and treated daily with $(10 \%$ Arabic Gum w/v), followed by the group fed on diet containing $10 \%$ protein and treated daily with (10\% Arabic Gum w/v).

The data presented in the table (1) showed that, there was a significant decrease $(\mathrm{p}<0.05)$ in the mean value of $\mathrm{BWG} \%$ for the positive control group fed on diet containing $2 \%$ arginine, as compared to the negative control group fed on basal diet. All treated groups fed on diets containing (5\%,10\% and $20 \%$ protein) showed significant increase in $\mathrm{BWG} \%$, as compared to the positive control group. On the other hand, non-significant change in $\mathrm{BWG} \%$ was observed between the groups fed on different levels from protein. Chronic renal failure groups fed on diets containing (10\% and $20 \%$ protein $)$ and treated or daily with $(10 \%$ Arabic Gum w/v) in the drinking water caused significant increase $\mathrm{p}<0.05 \mathrm{BWG} \%$, while feeding group of rats on diet containing 5\% protein and treated with Arabic Gum showed non-significant differences in $\mathrm{BWG} \%$, as compared to the positive control group. Body weight gain $\%$ of chronic renal failure groups which treated with Arabic Gum increased gradually with increasing the levels of protein in the diet.

Fed rats on diet containing $2 \%(\mathrm{w} / \mathrm{w})$ arginine $(20 \mathrm{~g} / \mathrm{kg}$ diet $)$ led to significant increase $\mathrm{p}<0.05$ in liver and kidney weights / body weight $\%$, as compared to healthy rats. All treated groups which fed on (diet containing some levels from protein) showed significant decrease $p<0.05$ in liver and kidney weights / body weight \% of chronic renal failure groups, as compared to the positive control group. Treating chronic renal failure group with diet containing low level from protein decreased the liver and kidney weights / body weight \% significantly, as compared to the group which treated with diet containing $20 \%$ protein. The results showed that, treating chronic renal failure groups with Arabic Gum solution showed significant decrease in liver and kidney weights / body weight $\%$, as compared to nontreated groups. The best results in liver and kidney weights / body weight $\%$ recorded for chronic renal failure fed on low protein diet and treated daily with Arabic Gum, because this group showed non-significant changes in liver \& kidney weights/body weight $\%$, as compared to the negative control group. 
Effect of diets contains different levels from protein in the presence of Arabic Gum on lipid profile of rats suffering from chronic renal failure.

The different investigated groups of rats were fed on the tested diets including three levels of the investigated protein in the presence of Arabic Gum to look forward towards the generation efficiency of blood lipids. Subsequently, different groups of rats during the whole period of experiment were estimated as presented in Table (2). The control group (+ve) which was suffering from chronic renal failure has shown a highly significant increase $\mathrm{p}<0.05$ in the mean value of serum cholesterol (150.409 $\pm 6.697 \mathrm{mg} / \mathrm{dl}$ ), compared with those of the negative control group (88.309 $\pm 5.429 \mathrm{mg} / \mathrm{dl}$ ). Feeding rats on Arginine diet (control +ve group) increased total serum cholesterol by about $70.321 \%$, than that of basal diet (control ve group). Feeding chronic renal failure groups on diet containing different levels from protein $(5 \%, 10 \%$ and $20 \%)$ and treated daily with $(10 \%$ Arabic Gum $w / v)$ in the drinking water caused a significant decrease $p<0.05$ in serum cholesterol, as compared to the positive control group. The best results in serum cholesterol recorded for the group fed on diet containing $5 \%$ protein and treated daily with (10\% Arabic Gum w/v) in the drinking water, this treatment decreased serum cholesterol by about $31.496 \%$ than that of the control +ve group.

Table 2: Effect of diets contains different levels from protein in the presence of Arabic Gum on lipid profile of rats suffering from chronic renal failure.

\begin{tabular}{||c||c|c|c|c|c||}
\hline \multirow{2}{*}{ Treatments } & \multicolumn{5}{|c||}{ (mg/dl) } \\
\cline { 2 - 6 } & Cholesterol & Triglycerides & HDL-c & LDL-c & VLDL-c \\
\hline \hline \multirow{2}{*}{ Control (-ve) } & $88.309 \mathrm{~g}$ & $45.226 \mathrm{~g}$ & $45.876 \mathrm{a}$ & $33.389 \mathrm{~h}$ & $9.045 \mathrm{~g}$ \\
& \pm 5.429 & \pm 3.096 & \pm 2.663 & \pm 2.228 & \pm 0.619 \\
\hline \multirow{2}{*}{ Control (+ve) } & $150.409 \mathrm{~b}$ & $90.745 \mathrm{~b}$ & $29.137 \mathrm{e}$ & $103.123 \mathrm{~b}$ & $18.149 \mathrm{~b}$ \\
& \pm 6.697 & \pm 3.249 & \pm 2.774 & \pm 3.576 & \pm 0.649 \\
\hline \multirow{2}{*}{$5 \%$ protein } & $126.517 \mathrm{~d}$ & $70.004 \mathrm{~d}$ & $38.819 \mathrm{c}$ & $73.697 \mathrm{e}$ & $14.000 \mathrm{~d}$ \\
& \pm 4.346 & \pm 3.658 & \pm 1.916 & \pm 2.362 & \pm 0.732 \\
\hline \multirow{2}{*}{$10 \%$ protein } & $137.831 \mathrm{c}$ & $77.899 \mathrm{c}$ & $32.960 \mathrm{~d}$ & $89.291 \mathrm{c}$ & $15.579 \mathrm{c}$ \\
& \pm 1.811 & \pm 2.859 & \pm 2.803 & \pm 2.357 & \pm 0.572 \\
\hline \multirow{2}{*}{$20 \%$ protein } & $159.338 \mathrm{a}$ & $103.339 \mathrm{a}$ & $26.632 \mathrm{e}$ & $112.038 \mathrm{a}$ & $20.668 \mathrm{a}$ \\
& \pm 4.709 & \pm 2.785 & \pm 2.512 & \pm 2.419 & \pm 0.557 \\
\hline \multirow{2}{*}{$5 \%$ protein $+\mathrm{AG}$} & $103.036 \mathrm{f}$ & $60.056 \mathrm{f}$ & $41.585 \mathrm{~b}$ & $49.440 \mathrm{~g}$ & $12.011 \mathrm{f}$ \\
& \pm 5.183 & \pm 2.917 & \pm 1.774 & \pm 3.053 & \pm 0.583 \\
\hline \multirow{2}{*}{$10 \%$ protein $+\mathrm{AG}$} & $112.096 \mathrm{e}$ & $64.675 \mathrm{e}$ & $38.673 \mathrm{c}$ & $60.488 \mathrm{f}$ & $12.935 \mathrm{e}$ \\
& \pm 4.603 & \pm 2.523 & \pm 2.056 & \pm 2.482 & \pm 0.505 \\
\hline \multirow{2}{*}{$20 \%$ protein $+\mathrm{AG}$} & $127.076 \mathrm{~d}$ & $68.373 \mathrm{~d}$ & $33.182 \mathrm{~d}$ & $80.219 \mathrm{~d}$ & $13.675 \mathrm{~d}$ \\
& \pm 4.427 & \pm 4.160 & \pm 2.443 & \pm 1.278 & \pm 0.832 \\
\hline
\end{tabular}

- AG: Arabic Gum - CRF: Chronic Renal Failure - Values are expressed as mean $\pm \mathrm{SD}$.

-Values which have different letters in each column differ significantly, while those with have similar or partially are not significant. - Significant at $\mathrm{p}<0.05$ using one way ANOVA test. 
The results in Table (2) indicated that, serum triglyceride increased gradually by increasing the levels of protein in the diet. On the other hand, the mean values of serum triglyceride decreased significantly $p<0.05$ in chronic renal failure groups which treated with Arabic Gum, comparing with non treated groups with Arabic Gum. The highest decrease in triglyceride between all treated groups recorded for the group fed on low protein diet treated with Arabic Gum, followed medium level. These treatments decreased serum triglyceride 33.818 and $28.728 \%$, respectively.

Treating chronic renal failure groups with diets containing $(5 \%$ and $10 \%$ protein) resulted in significant increase $\mathrm{p}<0.05$ in serum HDL-c, while chronic renal failure group which treated with $(20 \%$ protein) showed nonsignificant difference in this parameter, as compared to the positive control group. The other treated groups with different levels from protein with Arabic gum increased the mean values of serum HDL-c, as compared to the positive control group.

The best results in serum HDL-c, LDL-c recorded for the group fed on low protein diet $(5 \%)$ and treated daily with $(10 \%$ Arabic Gum w/v in the drinking water), followed by the group fed on medium level $(10 \%)$. The highest decrease in serum VLDL-c between all treated groups recorded for the group fed on low protein diet and treated daily with Arabic Gum, followed by the group fed on the medium protein diet and treated daily with Arabic Gum 33.82\% and 28.728\%, respectively.

Such results agree with those obtained by Mee and Gee (1997) they mentioned that the decrease was confined to LDL and VLDL cholesterol only, with no effect on HDL and triglycerides. Sicart and Sablé-Amplis (1987) noticed that, in 6 weeks the significant cholesterol-lowering effect. Total cholesterol dropped by $10 \%$ and LDL by $14 \%$, with no significant change in either HDL or triglyceride concentration.

\section{Correlation between histological changes in the kidney and its functions}

It is well recognized that urea is a major uremic toxin and plays an important role in human diseases. It is usually accepted that levels above $50 \mathrm{mmol} /$ liter induce anorexia. Furthermore, the level of blood urea is used for the clinical evaluation renal function, and it is considered as an indicator for the accumulation of all the nitrogen waste products producing from the degradation of protein Kely\& Mitch(1983) and Amin (1993). While AlMosawai, (2004) reported that, Gum Arabic is commonly prescribed for 
chronic renal failure in patients in Sudan; it results in decreased uraemia and reduces the frequency of dialysis, hence improving the quality of life.

From the results given in Table (3), it could be noticed that administration of $2 \% \mathrm{~L}$ - arginine for 30 days produced a significant increase $\mathrm{p}<0.05$ in serum uric acid, as compared to negative control group (4.374 \pm $0.147 \mathrm{mg} / \mathrm{dl}$ vs. $1.587 \pm 0.112 \mathrm{mg} / \mathrm{dl}$ ), respectively. Also it could be observed an improvement of serum uric acid at the end of experimental period after administration of diet containing low level from protein $(5 \%$ protein), while the administrated of diet containing ( $10 \% \& 20 \%$ protein) did not improve this parameter, as compared to the positive control group.

Table 3: Effect of diets contains different levels from protein in the presence of Arabic Gum on kidney function, serum sodium and potassium of rats suffering from chronic renal failure.

\begin{tabular}{||c|c|c|c|c|c||}
\hline \multirow{2}{*}{ Treatments } & \multicolumn{3}{|c|}{$\mathrm{mg} / \mathrm{dl}$} & \multicolumn{2}{c||}{$\mathrm{mmol} / \mathrm{l}$} \\
\cline { 2 - 6 } & Uric acid & Urea nitrogen & Creatinine & $\mathrm{Na}$ & $\mathrm{K}$ \\
\hline \hline Control (-ve) & $1.587 \mathrm{f}$ & $30.157 \mathrm{~h}$ & $0.577 \mathrm{f}$ & $137.732 \mathrm{a}$ & $3.500 \mathrm{~d}$ \\
& \pm 0.112 & \pm 1.912 & \pm 0.045 & \pm 7.327 & \pm 0.206 \\
\hline Control (+ve) & $4.374 \mathrm{~b}$ & $173.328 \mathrm{~b}$ & $4.162 \mathrm{~b}$ & $90.894 \mathrm{e}$ & $10.055 \mathrm{a}$ \\
& \pm 0.147 & \pm 4.001 & \pm 0.313 & \pm 4.074 & \pm 0.814 \\
\hline $5 \%$ protein & $3.268 \mathrm{c}$ & $139.323 \mathrm{~d}$ & $3.244 \mathrm{c}$ & $104.128 \mathrm{~d}$ & $7.874 \mathrm{~b}$ \\
& \pm 0.169 & \pm 5.300 & \pm 0.189 & \pm 4.281 & \pm 0.579 \\
\hline $10 \%$ protein & $4.194 \mathrm{~b}$ & $166.963 \mathrm{c}$ & $3.979 \mathrm{~b}$ & $100.120 \mathrm{~d}$ & $8.182 \mathrm{~b}$ \\
& \pm 0.457 & \pm 4.779 & \pm 0.183 & \pm 3.456 & \pm 0.587 \\
\hline $20 \%$ protein & $5.923 \mathrm{a}$ & $191.168 \mathrm{a}$ & $4.528 \mathrm{a}$ & $85.344 \mathrm{f}$ & $10.435 \mathrm{a}$ \\
& \pm 0.229 & \pm 4.691 & \pm 0.333 & \pm 4.312 & \pm 0.562 \\
\hline $5 \%$ protein & $2.255 \mathrm{e}$ & $88.838 \mathrm{~g}$ & $2.109 \mathrm{e}$ & $118.519 \mathrm{~b}$ & $6.500 \mathrm{c}$ \\
$+\mathrm{AG}$ & \pm 0.154 & \pm 5.419 & \pm 0.108 & \pm 4.015 & \pm 0.528 \\
\hline $10 \%$ & $2.889 \mathrm{~d}$ & $96.272 \mathrm{f}$ & $2.704 \mathrm{~d}$ & $113.826 \mathrm{~b} \mathrm{c}$ & $6.761 \mathrm{c}$ \\
protein+AG & \pm 0.250 & \pm 5.883 & \pm 0.139 & \pm 3.321 & \pm 0.572 \\
\hline $20 \%$ & $3.429 \mathrm{c}$ & $112.004 \mathrm{e}$ & $3.182 \mathrm{c}$ & $109.213 \mathrm{c}$ & $7.911 \mathrm{~b}$ \\
protein $+\mathrm{AG}$ & \pm 0.259 & \pm 4.263 & \pm 0.152 & \pm 2.935 & \pm 0.288 \\
\hline
\end{tabular}

- Na: Sodium. - K: Potassium. - AG: Arabic Gum - CRF: Chronic Renal Failure - Values are expressed as mean \pm SD. - Significant at $\mathrm{p}<0.05$ using one way ANOVA test. -Values which have different letters in each column differ significantly, while those with have similar or partially are not significant.

The highest decrease in serum uric acid recorded for the group fed on low protein diet and treated with $(10 \%$ Arabic Gum w/v) in the drinking water was $33.950 \%$, comparing with the positive control group. Feeding chronic renal failure groups on diets containing different levels from protein and treated daily with Arabic Gum decreased the mean value of urea nitrogen significantly, as compared to the positive control group. The best results in serum urea nitrogen recorded for the group fed on low protein diet (5\% protein), because this treatment showed significant decrease in this parameter, as compared to other treated groups. In this respect Frey, (2007) 
who published that the serum urea nitrogen is a substance that is formed in the liver when the body breaks down protein. In healthy people, most urea nitrogen is filtered out by the kidneys and leaves the body in the urine. If the patient's kidneys are not functioning properly or if the body is using large amounts of protein, the serum urea nitrogen level will rise.

The mean value of serum creatinine in the positive control group was $4.162 \pm 0.313 \mathrm{mg} / \mathrm{dl}$, while the respective value of the negative control group was $0.577 \pm 0.045 \mathrm{mg} / \mathrm{dl}$. The mean value of serum creatinine in the group (fed on low protein diet and treated with Arabic Gum) achieved the best results. This group recorded significant decrease in this parameter, as compared to other treated group. From obtained results, it can be noticed that, feeding rats on diet containing $2 \%$ arginine led to significant increase in serum uric acid, urea nitrogen and creatinine, as compared to healthy rats. Bliss et al. (1996) investigated that supplementation with gum Arabic fiber increases fecal nitrogen excretion and lowers serum urea nitrogen concentration in chronic renal failure patients consuming a low-protein diet. Younes et al., (1999) indicate that under these dietary conditions, the addition of oligosaccharides (gum Arabic) to the diet induced a 20 to $30 \%$ decrease in blood urea and renal and renal nitrogen excretion relative to the control, indicating a potential for oligosaccharide diet therapy in chronic renal disease.

Nasir et al., (2008) concluded that, treatment with GA resulted in moderate but significant increases of creatinine clearance and altered electrolyte excretion, i.e., effects favorable in renal insufficiency. AlMosawi (2004) reported that acacia gum supplementation of a low-protein diet in children with end-stage renal disease. the author concluded that, dietary supplementation with acacia gum may be an alternative to renal replacement therapy to improve the quality of life and reduce or eliminate the need for dialysis in children with ESRD in some developing countries. Ali et al., (2008) studied the effect of gum Arabic (Acacia Senegal) oral treatment on the metabolic profile of chronic renal failure (CRF) patients and found that, serum uric acid, urea nitrogen and creatinines showed significantly decreased in the groups of gum Arabic and conclude that oral administration of gum Arabic could conceivably alleviate adverse effects of CRF.

In Fig (1) the histology changes were noticed in kidney in different treatment diet. (Ali, et al.;2010) mention that, GA (6\% and $12 \%$ in drinking water for four consecutive weeks) significantly ameliorated the adverse 
biochemical alterations indicative of renal failure, abated the decrease in body weight and reduced the glomerular, tubular and interstitial lesions induced by adenine. This study provides evidence that GA attenuated renal dysfunction in this model of CRF, suggesting a promising potential for it in protecting against renal failure progression.

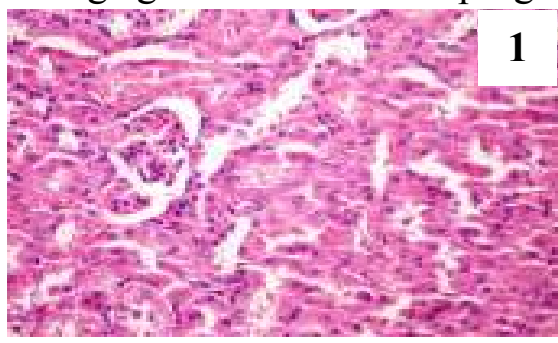

control-ve (H and E x 400)

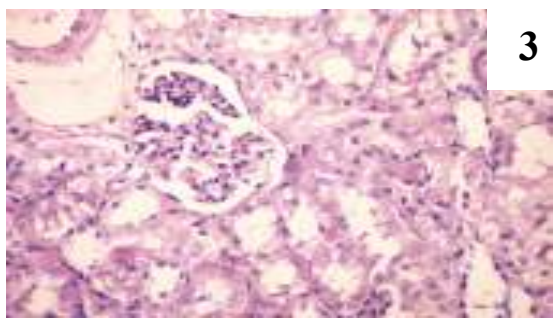

Protein 5\% (H and E x 400)

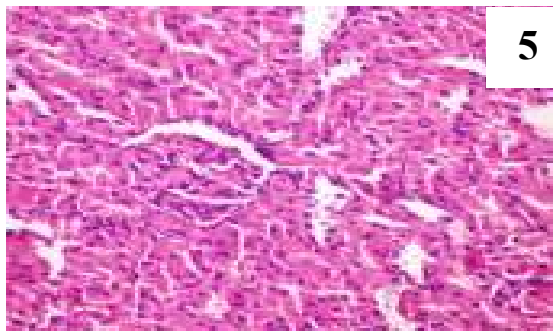

Protein 20\% (H and E x 400)

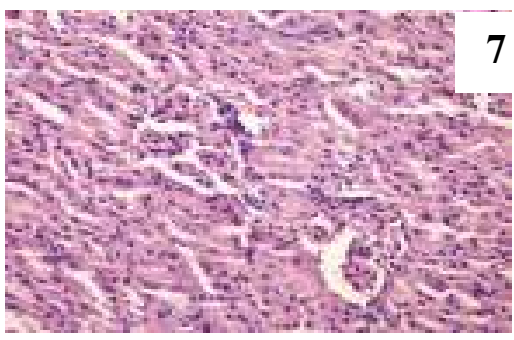

Protein $10 \%+\mathrm{AG}(\mathrm{H}$ and $\mathrm{E} \times \mathrm{400})$

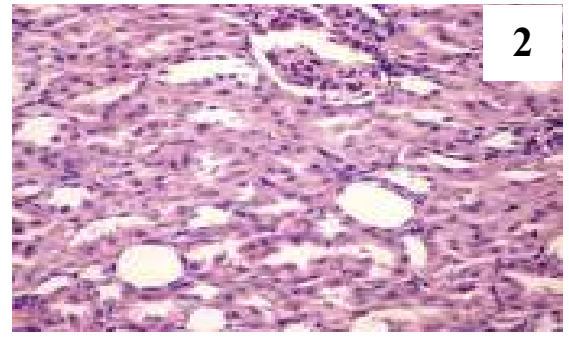

control+ve (H and E x 400)

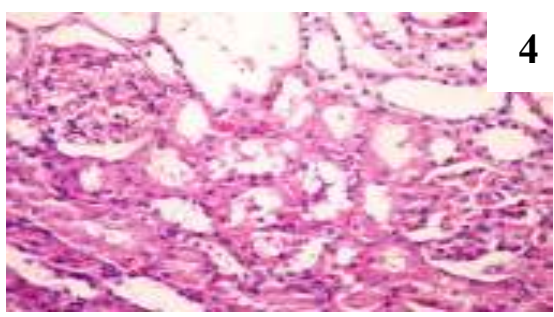

Protein $10 \%(\mathrm{H}$ and $\mathrm{E} \mathrm{x} \mathrm{400)}$

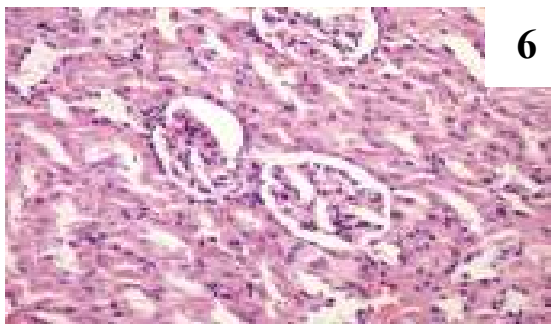

Protein 5\% $+\mathrm{AG}(\mathrm{H}$ and $\mathrm{E} x \mathrm{400})$

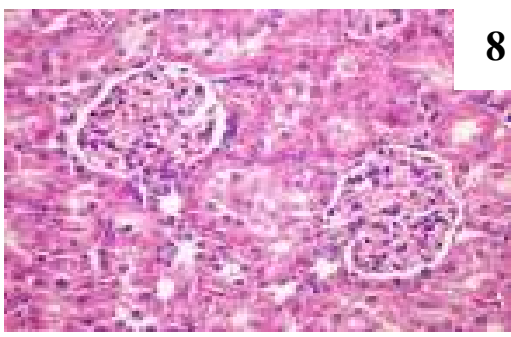

Protein $20 \%+\mathrm{AG}(\mathrm{H}$ and $\mathrm{E} \times \mathrm{400})$

Fig. 1: Histopathological changes in kidneys. 
1) control -ve rat revealed the normal histological structure of renal parenchyma; 2) control +ve rat showed cystic ohilation of some renal tubules; 3) hypertrophy of glomerular tufts; 4) showed vascular degeneration of renal tubular epithelium; 5,6,7) no histopathological changes, 8) showed vascular degeneration of epithelial liming some renal tubules.

From the obtained results in Table (3) it could be deduced that chronic administration of L-arginine due to abnormal changes in serum sodium and potassium levels. With regard to serum sodium levels, it could be observed that through the experimental period there were a significant decrease $(\mathrm{P}<0.05)$ in serum sodium of rats with chronic renal failure, as compared to the negative control. There were significant increases in serum sodium levels in all treated groups, except group of rats fed on diet containing $20 \%$ protein, as compared to the positive control group. Feeding chronic renal failure group on diet containing 5\% protein and treated daily with Arabic Gum increased serum sodium by about $30 \%$, than that of the positive control group.

On the other hand feeding rats which suffer from chronic renal failure with diets containing $(5 \%, 10 \%$ and $20 \%$ protein) and treated them with Arabic Gum led to decrease serum potassium significantly $\mathrm{p}<0.05$, as compared to the positive control group. The highest decrease in serum potassium recorded for the groups fed on high protein diets with or without treatment by Arabic Gum. These result was agree with Giebisch (2007) who observed that a serum potassium level is apparent even among people with chronic renal failure insufficiency.

\section{Correlation between histological changes in the liver and its function:}

Effect of feeding rats on diets containing different levels from protein $(5 \%, 10 \%$ and $20 \%)$ with treated or non-treated with Arabic Gum on the liver enzymes aspartate amino transferase (AST) and alanine amino transferase (ALT) in serum of rats suffering from chronic renal failure was illustrated in Table (4). Feeding rats on arginine diet increased serum AST and ALT enzymes $57.767 \%$ and $176.168 \%$, respectively. In this respect, Abd-ELFattah et al., (2006) revealed that the high levels of AST \&ALT in serum are indicators for liver dysfunction. This significant increasing may be attributed mainly to the hepatotoxic effect of arginine.

As shown in this Table, feeding groups of rats which were suffering from chronic renal failure on diets containing $5 \%$ and $10 \%$ protein recorded 
a significant decrease $\mathrm{p}<0.05$ in these enzymes, while feeding chronic renal failure rats on diet containing (20\% protein) increased AST and ALT enzymes, as compared to the positive control group.

Feeding rats which suffer from chronic renal failure on diets containing different levels from protein $(5 \%, 10 \%$ and $20 \%)$ and treated with $(10 \%$ Arabic Gum w/v) led to significant decrease $\mathrm{p}<0.05$ in AST \& ALT enzymes, as compared with positive control group. The highest decrease in AST \& ALT enzymes recorded for the groups fed on low protein diet and treated them with $(10 \%$ Arabic Gum w/v) in the drinking water, followed by the group fed on medium protein diet with the same treatment.

Gmal al-Din et al (2003)Arabic gum is effective in protecting mice against acetaminophen-induced hepatotoxicity. This protection may involve the reduction of oxidative stress.

In experimental rats, the histology changes were noticed in liver in different treatment diet Fig (2).

Table 4: Effect of diets containing different levels from protein in the presence of Arabic Gum on liver enzymes of rats suffering from CRF.

\begin{tabular}{||c|c|c|}
\hline \multirow{2}{*}{ Treatments } & \multicolumn{2}{|c|}{$\mathrm{U} / \mathrm{L}$} \\
\cline { 2 - 3 } & AST & ALT \\
\hline \hline Control (-ve) & $61.064 \pm 2.018 \mathrm{e}$ & $21.161 \pm 1.336 \mathrm{e}$ \\
\hline Control $(+\mathrm{ve})$ & $96.339 \pm 4.282 \mathrm{a}$ & $58.440 \pm 3.495 \mathrm{a}$ \\
\hline $5 \%$ protein & $88.376 \pm 3.3167 \mathrm{~b} \mathrm{c}$ & $49.254 \pm 3.181 \mathrm{~cd}$ \\
\hline $10 \%$ protein & $89.825 \pm 3.072 \mathrm{~b}$ & $51.855 \pm 3.549 \mathrm{~b} \mathrm{c}$ \\
\hline $20 \%$ protein & $98.502 \pm 5.349 \mathrm{a}$ & $57.252 \pm 4.260 \mathrm{a}$ \\
\hline $5 \%$ protein $+\mathrm{AG}$ & $76.519 \pm 3.187 \mathrm{~d}$ & $47.185 \pm 1.452 \mathrm{~d}$ \\
\hline $10 \%$ protein $+\mathrm{AG}$ & $85.055 \pm 3.091 \mathrm{c}$ & $49.636 \pm 2.123 \mathrm{bcd}$ \\
\hline $20 \%$ protein $+\mathrm{AG}$ & $88.603 \pm 1.625 \mathrm{~b} \mathrm{c}$ & $52.841 \pm 2.819 \mathrm{~b}$ \\
\hline
\end{tabular}

- AST: aspartate amino transferase - ALT: alanine amino transferase.

- AG: Arabic Gum - CRF: Chronic Renal Failure - Values are expressed as mean \pm SD. - Significant at $p<0.05$ using one way ANOVA test. -Values which have different letters in each column differ significantly, while those with have similar or partially are not significant.

These results are in broad agreement with Mariusz et al. (1996) who found that chronic renal failure is associated with multiple disturbances in other organs as liver as down regulation of the mRNA of the liver enzymes. 
On the other side, Akmal (2000) found that chronic renal failure associated with an impairment of liver functions. Yokozawa et al., (2003) confirmed that excess L-arginine lead to impairment in liver functions.

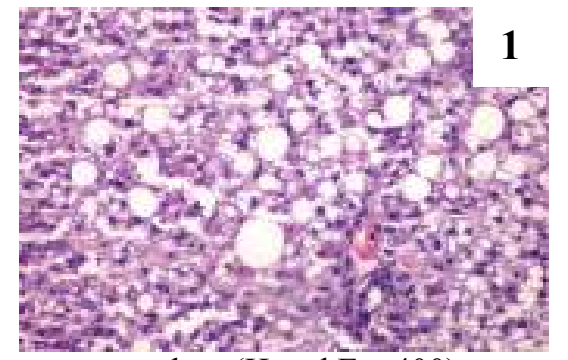

control-ve (H and $\mathrm{E}$ x 400)

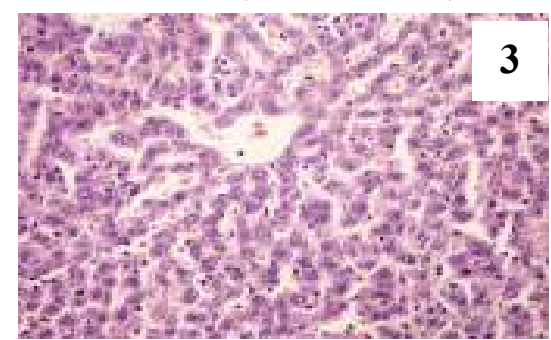

Protein 5\% (H and E x 400)

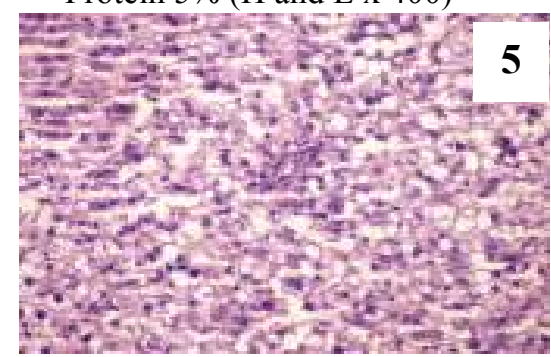

Protein 20\% (H and E x 400)

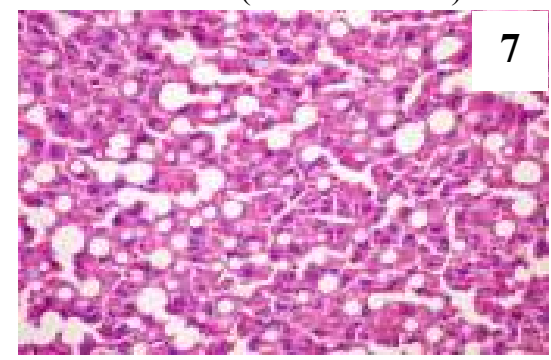

Protein $10 \%+\mathrm{AG}(\mathrm{H}$ and $\mathrm{E} x \mathrm{400})$

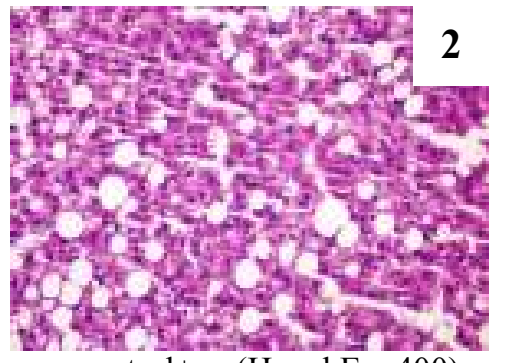

control+ve (H and E x 400)

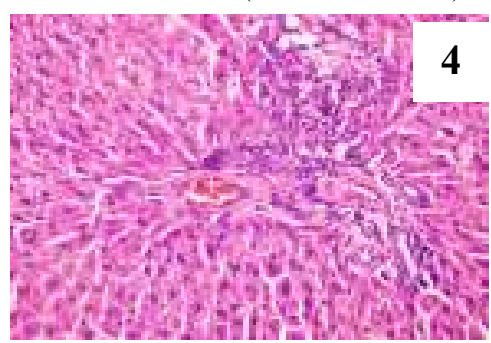

Protein $10 \%(\mathrm{H}$ and $\mathrm{E} \times \mathrm{400})$

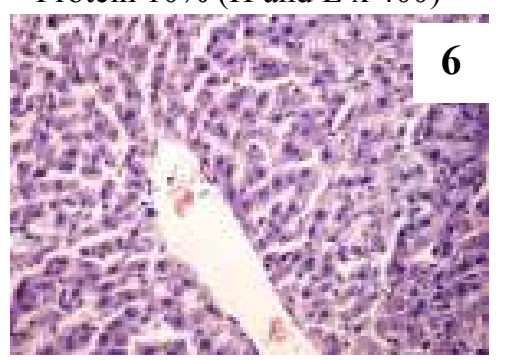

Protein 5\% $+\mathrm{AG}(\mathrm{H}$ and $\mathrm{E} x \mathrm{400})$

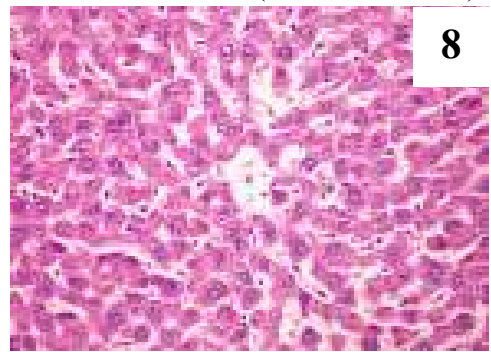

Protein $20 \%+\mathrm{AG}(\mathrm{H}$ and $\mathrm{E} \times \mathrm{400})$

Fig. 2: Histopathological changes in liver. 
1) control -ve rat revealed the normal histological structure of renal parenchyma; 2,3) control +ve revealed fatty change of hepatocytes; 4) showed kupffer cells activation and presence of small vascular in the cytoplasm of some hepatocytes; 5) revealed small vascular in the cytoplasm of hepatocytes as well as portal infiltration with leucocytes; 6) showed cytoplasmic vacuolization of hypatocytes; 7) revealed kupffer cells activation and small vacuoles in the cytoplasm of hepatocytes; 8) revealed no histopathological changes. 


\section{References:}

- Abd EL-Fattah,A.M.; Mastumoto,K. \& Watanabe,H. (2006). Antinociceptire effects of nigella sativa oil and its major component, thymoquinone in mice. Eur.J. Phormacol.400:89-97.

- Abdulhakeem, A. A.; Adel, M. M.; Ammar, C. A. and Othman, A. A. (2002). Protective effects of oral Arabic Gum administration on gentamicin induced nephrotoxicity in rats. Pharmacological Research 46 (5): 445-451.

- Akmal, M.; Kasim, C. E.; Soliman, A. R. and Massry, S. G. (2000). Excess parathyroid hormone adversely affects lipid metabolism in chronic renal failure. Kidney Int.; 37:845-858.

- Ali, B. H.; Al-Salam, S.; Al-Husseni, I.; Kayed, R. R.; Al-Masroori, N.; AlHarthi, T.; Al-Zaabi, M.; Nemmar, A. (2010). Effects of Gum Arabic in rats with adenine-induced chronic renal failure.; Experimental Biology and Medicine.; 235: 3, 373-382.

- Ali ,A.A.;Ali, K.E.;Fadlalla, A.E. and Khalid, K.E.(2008). The effects of gum arabic oral treatment on the metabolic profile of chronic renal failure patients under regular haemodialysis in Central Sudan. Nat . Prod.Res.,22(1):12-21.

- Allain, C.C. (1974). Enzymatic colourimetric method of the determination of plasma total cholesterol. Clin. Chem. 20: 470.

- Al-Mosawai, A. J. (2004). Acacia gum supplementation of a low-protein diet in children with end-stage renal disease.; pediatr, Nephrol.; 19: 1156-1159.

- Amin , A.A. (1993). Study effect of different levels and kinds of proteins on chronic renal failure rats .Thesis PH.D.Nutrition and Food Science . Faculty of Home Econ . Helwan Univ .

- Assmann, G.; Jabs, H.U.; Kohnert, U.; Nolte, W. \& Schriewer, H. (1984). LDL_Cholesterol determination in blood serum following precipitation of LDL with polyvinlysulfate. Clin. Chim. Acta 140:77-83.

- Bliss, D.Z.; Stein, T.P.; Schleifer, C.R. and Settle, R.G.(1996): Supplementation with gum arabic fiber increases fecal nitrogen excretion and lowers serum urea nitrogen concentration in chronic renal failure patients consuming a low-protein diet. Am. J. Clin. Nutr.,63(3):392-398.

- Bohmer, H.B.U. M. (1971). Micro - determination of creatinine .Clin. Chem . Acta., 32 : 81-85.

- Denis, F.; Ping, W.; Maurice, L. and Jean-pierre, B. (2000). Low protein diets delay end-stage renal disease in non-diabetic adults with chronic renal failure. Nephrol. Dial. Transplant, 15: 1986-1992.

- Drury, R.A. \& Wallington, E.A. (I980). Carton's Histological Technique. 5th. Oxford University. 
- Fossati, F. \& Principe, L. (1982). Plasma triglycerides determined colorimetrically with an enzyme that produces hydrogen peroxide. Clin. Chem., 28 (10): 2077-2080.

- Fossati, P.; Prencipe, L. and Berti, G. (1980). Uric acid enzymatic colorimetric method. Clin. Chem. 26(2): 227-273.

- Frey, R.J. (2007). Blood urea nitrogen test health aticle.http://www.healthline .com/galecontent/blood-urea-nitrogen-test.

- Gamal al-Din, A.M.; Mostafa, A.M.; Al-Shabanah, O.A.; Al-Bekairi, A.M. and Nagi, M.N. (2003). Protective effect of arabic gum against acetaminophen-induced hepatotoxicity in mice. Pharmacol. Res., 48(6):631635.

- Giebisch, G. (2007). Renal potassium transport : mechanisms and regulation. Am. J. Renal Physiol.; 274: 817-833.

- Henry, J. B.; Todd, M. K.; Sanford, L. U. and davidsohn, S. G. (1974). Clinical Diagnosis and Measurement by Laboratory Methods. 16 th Ed. W. B. Saunders and CO., Philadelphia, P. A. PP.260.

- Kelly,R. \& Mitch,w. (1983). Creatinine, uric acid and other nitrogenous waste products: clinical implication of imbalance between their production and elimination in uremia. Semin. Nephrol.3:286-294.

- Locatelli, F. (2004). Low protein diet in uremia: Effect on glucose metabolism and energy production rate. Kidney Int.; 51: 1222-1227.

- Lopes-Virella, M. (1977). Cholesterol determination in high density lipoproteins separated by three different methods. Clin. Chem.; 23: 882.

- Mariusz, K.; Miroslaw, S.; Zhenmin, N.; Guoxiang, Z. and Shaul, G. (1996). Abnormalities in hepatic lipase in chronic renal failure.The Amirican Society for Clinical Investigation, Iinc. 97(10): 2167-2173.

- Nasir, O.; Artunc, F.; Saeed, A.; Kambal, M.A.; Kalbacher, H.; Sandulache, D.; Boini, K.M.; Jahovic, N. and Lang, F. (2008): Effects of gum arabic (Acacia senegal) on water and electrolyte balance in healthy mice. J. Ren. Nutr. Mar; 18 (2):230-8.

- Patton, C. J. and Crouch, S. R. (1977). enzymatic colorimetric method for determination of uric in serum. Anal. Chem., 49:464-469.

- Phillips, G.O. (1998). Acacia gum (G.A.): a nutritional fibre; metabolism and caloric value.; Food Addit. ;Contam. 15, 251-264.

- Reeves , P.G.; Nielsen ,F.H and Fahmy , G. C.(1993): Report of The American Institute of Nutrition adhoc wriling committee on the reformulation of the AIN -76A Rodent diet. J Nutr., 123: 1939-1951.

- Reitman, S. and Frankel, S. (1957). A colourimetric method of the determination of plasma glutamic oxaloacetic and glutamic pyruvic transaminases. Am. J. Clins. Pathol., 28: 56-63. 
- SAS. (1996). SAS/ Stat User's Guide: Statistics, System for Windows, version 4.10 (release 6.12 TS level 0020), SAS Inst., Inc. Cary, North Carolina, USA.

- Sheehan, D. \& Harpchak, B. (1980). Phory and bractec histotechnology. 2nd edn. Battle-Press; Ohio.

- Snedecor, G.W. and Cochran, W.G. (1980). Statistical Methods. 7th Ed. Oxford and J. B.H. Publishing Co.

- Yokozawa, T.; Cho, E. J. and Nakagawa, T. (2003). Influence of green tea polyphenol in rats with arginineinduced renal failure. J. Agric. Food. Chem.; 51: 2421-2425.

- Younes, H.; Alphones, J. C. and Behr, S. R. (1999). Role of fermentable carbohydrate supplements with a low-protein diet in the course of chronic renal failure: experimental bases. American Journal of Kidney Diseases 33, 633-46. 


\section{تأثير المعاملة بالصهمغ العربي علي الفئران المصابة بالفشل الكلوى المزهن}

\section{دراسة بيولوجية}

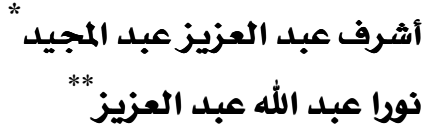

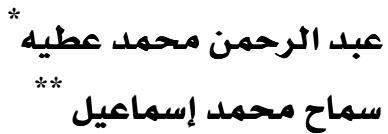

الملـخص العـربى

صممت هذه الدراسة لمعرفة تأثير الوجبات المحتوية علي مستويات مختلفة من البروتين مـع

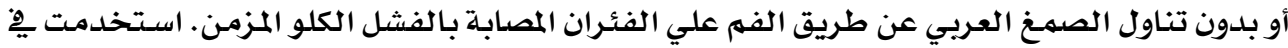

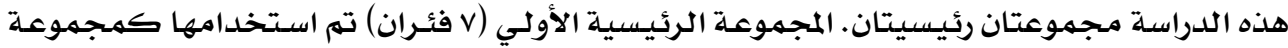

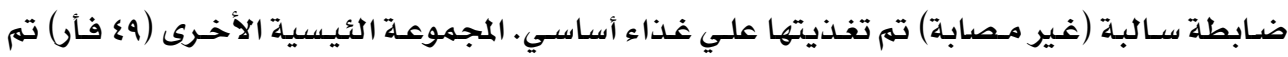

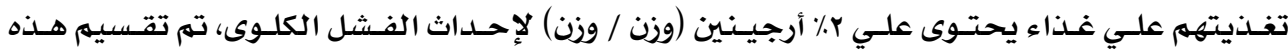
المجموعة الي سبعة محموعات فرعيـة (v فئران لكل مـنهم) ـ الممجموعة الفرعيـة الأولى تم تغذيتها

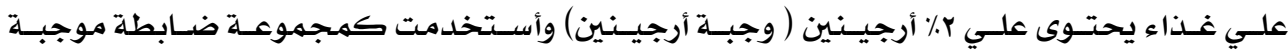
(مصابة). المجموعات الفرعيـة الثانيـة والثالثـة والرابعـة تم تغـذيتهم علي وجبـات الارجينـين المحتويـة

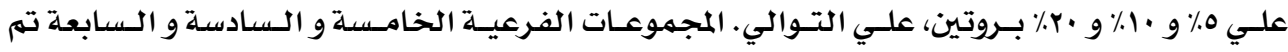
تغـذيتهم علسي وجبـات الأرجيــين المحتويسة علسي نفس نسب الـبروتين السسابقة كهـا تم معـاملتهم

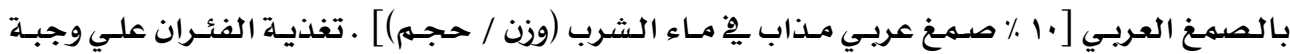

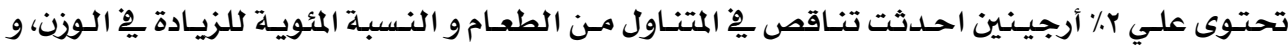

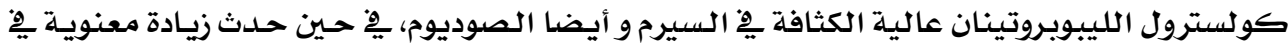

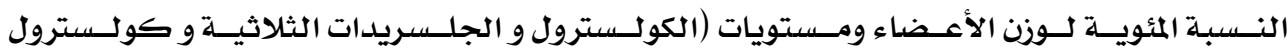

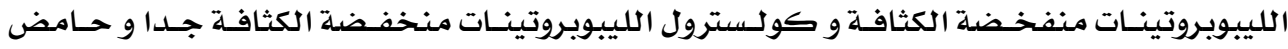
اليوريك و نيتروجين اليوريـا والكرياتينين والبوتاسيوم وانزيمـات الكبد بِّ سيرم دم الفئـران)، مقارنـة بالمجموعة السالبة التى تم تغذيتها علي غذاء أساسي. معاملة الفئران المصابة بالفشل الكلوى المزمن بالمستويات المتوسطة والمنخفضة مـن البروتين ادت الي حسدوث تحسن يِّ هـذه التقديرات، وخاصـة مـع المستوى المنـخفض مـن البروتين. مـن ناحيـة

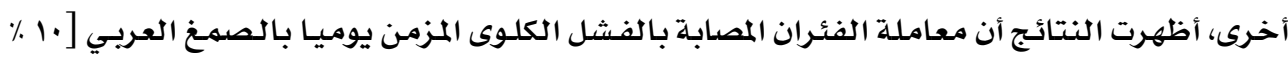

* قسم التغذية وعلوم الأطعمة - كلية الأقتصاد المنزلى - جامعة حلوان - القاهرة - جمهورية مصر العربية

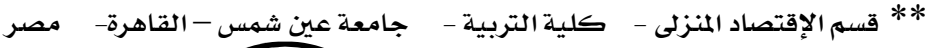


_Effect of Treatment with Arabic Gum on Rats Suffering from Chronic Renal Failure

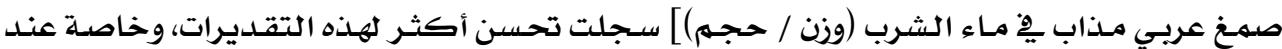
إستخدام الصمـغ العربي مـع المستوى المنخفض من البروتين.

اقترحت الدراسـة أن استخدام الصهـخ العريـي مـع اتبـاع نظام غذائي مسنخفض البروتين يجـب أن

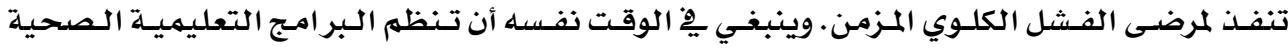
والغذائية الموجهة للجمهور لحماية أنفسهم من هذا المرض.

الكلمـات المفتاحيـة: الصهـغ العربـي - فئـران البينـوا - أرجيــين - الفـشل الكلـوى المزمن - صـورة الدهن - وظائف الكلي - انزيمات الكبد. 